\title{
Representasi Perempuan dalam Film Bernuansa Islami
}

Syiqqil Arofat

Magister Universitas Indonesia

syiqqil@gmail.com

\begin{abstract}
This writing shows that work of film which signs and defines realities through separation and election on network meaning according to certain view, has limited audiences' paradigm in defining their social realities; as if what given by film is a usual happening and should be a direction for the audiences to behave and act. The direction then is tightly attached with identification for differing between good and bad, wrong and right, friend and foe, us and them, even the most liked by the audiences: sexual differentiation between man and woman. In this respect, to be a man or woman is presented as a different experience and cannot be the same in terms of behavior, action and role in whole life aspects. By this meaning construction, cultural hegemony starts.
\end{abstract}

Keywords: Film, Social construction, Cultural.

Abstrak: Tulisan ini menunjukkan bahwa cara kerja film yang menandai dan memaknai realitas melalui proses pemilahan dan pemilihan jejaring pemaknaan, sesuai dengan sudut pandangan tertentu, telah membatasi pandangan penonton dalam memaknai realitas sosialnya, seolah yang disajikan dalam film merupakan sesuatu yang lumrah terjadi dan patut menjadi acuan penonton dalam bersikap dan berperilaku. Acuan tersebut melekat erat dengan identifikasi terhadap pembedaan antara yang baik dan yang buruk, benar dan salah, kawan dan lawan, kami dan mereka, dan bahkan yang paling digemari penonton: pembedaan seksual antara laki-laki dan perempuan. Menjadi laki-laki atau perempuan disajikan sebagai pengalaman yang berbeda dan tak boleh sama dalam bersikap, berperilaku dan berperan dalam setiap aspek kehidupan. Dengan konstruksi pemaknaan tersebut, hegemoni kultural pun dimulai.

Katakunci: Film, Konstruksi sosial, Kultural. 


\section{Pendahuluan}

Banyak pakar keilmuan di berbagai bidang memercayai, saat ini dunia kehidupan diwarnai pertarungan ideologis dan politis. Pada era ini, beragam macam dan bentuk pengaruh hadir dalam kehidupan individu tanpa seluruhnya dapat terdeteksi. Antony Giddens menyebut era ini sebagai runaway world (dunia yang lepas kendali.) ${ }^{1}$ Tak ada ruang personal yang mampu mengelak dari gempuran ideologis yang dikonstruksi dan diproduksi dalam kehidupan sosial, melalui sistem komunikasi canggih, direpresentasikan sangat menarik, dan kemudian turut membentuk kesadaran personal dan sosial.

Bagaimana sebuah ideologi dikonstruksi, diproduksi, direpresentasikan, dan disebarluaskan, merupakan persoalan yang tak pernah habis dibahas dan diperdebatkan dalam kajian sosial dan budaya. Tema ini kian mendapat sorotan, menyadari kian menguatnya konsekuensi-konsekuensi praktis yang melekat di dalamnya. Konstruksi ideologis tersebut sering memengaruhi cara pandang masyarakat tentang realitas sosial. Sehingga tak heran, dengan mengacu pada konstruksi ideologis tersebut, masyarakat cenderung memertahankan tatanan sosial tertentu tanpa direfleksikan kembali.

Ideologi sering dimaknai sebagai cara pandang yang disebarkan secara sadar dan konsisten oleh kalangan tertentu, yang dalam tataran praksis menjadi alat hegemoni. Namun bertentangan dengan makna tersebut, kajian budaya memaknai ideologi sebagai cara pandang yang tak sepenuhnya terbentuk secara sadar, tapi terbentuk melalui proses panjang pemaknaan dalam konteks sosial tertentu, yang mengental dalam sejarah, hingga tak pernah disadari dan terus dipertahankan berbagai kalangan. Karenanya, ideologi bukanlah alat untuk memertahankan kekuasaan atau merepresi mereka yang lemah, tapi lebih merupakan wacana atau konstruksi makna yang diproduksi dan disebarluaskan, beserta konsekuensi-konsekuensi politis pada tiap relasi sosialnya. ${ }^{2}$ Ini tak lain sebab pemahaman individu tak tumbuh dalam ruang hampa, tapi terbentuk dari berbagai komponen yang mengitari kehidupannya sejak kecil, yang kemudian melebur dalam emosi dan pikirannya. Melalui proses interaksi dengan kehidupan di sekitarnya, menurut Herbert Mead, manusia berupaya mengonstruksi dan memertahankan pranata sosial tertentu. ${ }^{3}$ Wacana atau konstruksi 
makna itulah yang kemudian dijadikan acuan setiap individu dalam berperan atau menyikapi realitas sosial.

Pada saat itulah media hadir menawarkan dan menyosialisasikan konstruksi ideologis kepada masyarakat. Seiring dengan perkembangan teknologi, media dianggap yang paling berperan dalam penyebaran ideologi dengan memanfaatkan kecanggihan sistem komunikasi. Dan di antara berbagai jenis media, film memiliki posisi istimewa dalam kajian sosial dan budaya, sebab filmlah yang dianggap paling berhasil menghipnotis para penonton dengan perpaduan efek suara dan gambar. ${ }^{4}$ Sehingga penonton mudah terhanyut dalam alur cerita, menghayati karakter-karakter yang dilekatkan pada para aktornya, terpengaruh konstruksi makna yang sebenarnya dibentuk secara fiktif, dan akhirnya menerimanya sebagai yang seharusnya terjadi. Saat itulah terjadi naturalisasi makna: konstruksi makna yang dihadirkan terus menerus sangat mungkin dianggap lumrah dalam realitas sosial.

Kajian gender pun memberi perhatian tersendiri terhadap perkembangan media, sebab ideologi yang disebarkan media selalu menyertakan 'tubuh' sebagai ruang pemaknaan: berangkat dari pembedaan identitas perempuan atau laki-laki. Begitu pula dalam film, para aktor membawa identitas seksual yang direpresentasikan memiliki karakter berbeda. Lalu dari pembentukan identitas tersebut, peran-peran kultural ditetapkan: perempuan memiliki peran yang berbeda dari laki-laki. Meski berbagai kajian menyatakan bahwa film tak serta merta memengaruhi penonton, berdasarkan latar belakang penonton yang beragam, konstruksi makna yang terus diproduksi secara luas dan dihadirkan terus-menerus memiliki potensi besar dalam memengaruhi kehidupan penonton.

Sementara itu, film-film yang bernuansa Islami, selain banyak diminati penonton Indonesia yang mayoritas Muslim, memiliki potensi tersendiri dalam memengaruhi penonton Muslim, sebab agama yang dianggap berada dalam ruang sakral, meski batas kesakralannya terus diperselisihkan, memiliki tata cara tersendiri dalam berperan dan bersikap yang tak boleh dibuat-buat. Karenanya, masyarakat Muslim dituntut mencari acuan makna untuk menjadi Muslim yang baik, tanpa memertimbangkan beragam konsekuensinya dalam tataran praktis. Sehingga tak heran kalau penonton Muslim 
terjerat dalam konstruksi makna tentang bagaimana menjadi Muslim yang baik yang dihadirkan dalam film bernuansa Islami. Dalam hal inilah hegemoni makna mewujud.

\section{Representasi Identitas}

Saat terlahir di dunia, tak seorang pun langsung tahu siapa dirinya dan kehidupan sosial yang mengitarinya. Tahap demi tahap, ia coba membangun pemahaman tentang kehidupan di sekitarnya, melalui makna-makna yang ditemuinya, terus menyusun menjadi sebuah pemahaman, melebur dalam emosinya, dan cenderung dipertahankan dalam melihat identitas dirinya. Setiap sesuatu yang tampak atau ditampakkan, yang menyiratkan identitas kelompok tertentu, sebagai cara untuk membicarakan atau memahami realitas sosial, itulah yang dimaksud dengan representasi. ${ }^{5}$ Dengan kata lain, representasi terkait dengan persoalan tentang bagaimana kehidupan dikonstruksi dan disajikan kepada dan oleh kita. ${ }^{6}$ Karenanya, untuk memahami representasi, kita harus memelajari asal-usul tektual dari makna, sebab representasi makna memiliki sifat material: ia terdapat dalam bentuk tulisan, gambar, majalah, buku, dan tayangan televisi. Lalu makna-makna tersebut dipahami dan dipraktikkan dalam konteks sosial yang spesifik. Pemahaman itulah yang kemudian menjadi pijakan bersikap dan berperan dalam interaksi sosialnya.

Dengan demikian, identitas sepenuhnya bersifat kultural, karena diciptakan melalui proses sosialisasi. Diri yang yang tersosialisasi inilah yang disebut Stuart Hall sebagai Subyek sosiologis. Menurutnya, Subyek atau individu tidaklah otonom, tapi terbentuk dalam hubungan dan pembedaan dengan 'si lain yang penting'-orang lain yang dianggap menempati posisi tertentu dalam kehidupannya, yang menjembatani nilai-nilai, makna-makna, serta tanda-tanda yang berada di sekitar Subyek. ${ }^{7}$ Salah satu contoh si lain yang penting' adalah anggota keluarga, sahabat, tetangga, dan sebagainya, sebagai tempat belajar cara menjalani kehidupan sosial melalui pujian, hukuman, peniruan, dan bahasa. Sejak kecil, manusia diajari memahami beragam posisi tersebut dan bagaimana bersikap dan berinteraksi dengan setiap posisi. Misalnya, berinteraksi dengan kerabat, tetangga dan sahabat akan berbeda, bahkan perlakuan seorang ibu terhadap 
anak laki-laki dan anak perempuan selalu berbeda. Perempuan harus bersikap lembut, sementara laki-laki tak boleh cengeng.

Representasi terkait dengan praktik pemaknaan yang berpotensi menciptakan identitas: yaitu tentang bagaimana seseorang terindetifikasi dengan gambaran-gambaran sebagai laki-laki atau perempuan, tua atau muda, berkulit hitam atau putih, dan Muslim atau non-Muslim. Identifikasi tersebut tak hanya dalam bentuk fisik, tapi juga sikap dan prilaku dalam interaksi sosialnya.

Identitas merupakan konstruksi diskursif, produk wacana atau cara tertentu dalam berbicara dan memahami baik dirinya sendiri maupun orang lain di sekitarnya. ${ }^{8}$ Karenanya, Laclau dan Mouffe memahami individu sebagai 'posisi Subyek' dalam struktur kewacanaan. ${ }^{9}$ Ini karena wacana selalu menetapkan posisi-posisi agar ditempati individu-individu sebagai Subyek. Dengan kata lain, identitas dikonstruksi melalui pembedaan dan pemilahan beragam representasi Subyek dalam posisi tertentu. Dari pembedaan representasi identitas itulah manusia berinteraksi dalam tatanan sosial dengan cara beragam, sebab pola interaksi tak lepas dari konstruksi identitas yang dilekatkan pada masing-masing individu.

\section{Konstruksi Sosial}

Selain konstruksi identitas yang dilekatkan pada Subyek, terdapat kecenderungan untuk mengonstruksi atau menetapkan peran-peran tertentu terhadap masing-masing identitas. Proses penetapan dan pengambilan peran tertentu dalam dinamika sosial itulah yang disebut Herbert Mead sebagai generalized other. ${ }^{10}$ Menurutnya, dinamika sosial selalu disertai harapan-harapan atau standar-standar umum yang menjadi dasar terbentuknya pranata sosial.

Dalam ungkapan senada, Herbert Blumer memandang peran dan formasi sosial sebagai proses berkembangnya interaksi sosial yang membentuk kondisi-kondisi tertentu bagi tindakan-tindakan individu. ${ }^{11}$ Pembagian peran tak berada dalam ruang kososng, tapi selalu terikat pada konteks historis atau situasi tertentu yang melatari terbentuknya formasi sosial. Karenanya, formasi sosial dapat dilihat sebagai struktur sosial yang menempatkan individu dalam posisiposisi tertentu dalam berinteraksi pada situasi bersama. 
Dalam teori dramaturgi Erving Goffman, setiap individu memroyeksikan dirinya melalui proses interaksi sosial dalam berperan dan bersikap untuk membangun pemahaman bersama (shared understanding. ${ }^{12}$ Apa yang ditampilkan oleh individu saat berinteraksi merupakan sebuah pemahaman bersama yang hampir tak mungkin diselewengkan, jika tak ingin menimbulkan kekacauan. Dengan kata lain, struktur sosial yang dibangun masyarakat berangkat dari konstruksi identitas yang telah mengakar, menyebar, dan terus dipertahankan di sepanjang sejarah.

Anggapan dasar pandangan sosiologis terhadap Subyek adalah bahwa manusia merupakan makhluk ciptaan sosial. Berdasarkan hubungan dengan orang-orang yang ditempatkan dalam posisi tertentu itulah seseorang membangun relasi sosialnya. Meski demikian, dengan mengutip David Morley, John Storey menyatakan bahwa Subyek sosial selalu diinterpelasi oleh sejumlah wacana: beberapa di antara wacana itu paralel dan saling menguatkan; namun ada juga beberapa wacana yang bertentangan, menghalangi atau mengubah interpelasi yang berhasil ditetapkan terhadap Subyek oleh wacana-wacana lainnya. ${ }^{13}$

\section{Hegemoni Kultural}

Meski konstruksi identitas memiliki pola yang beragam, terdapat perangkat makna dominan yang dianggap berada di atas angin. Proses penciptaan, pemeliharaan, dan reproduksi perangkat makna secara otoritatif ini, seperti dinyatakan Antonio Gramsci, disebut sebagai hegemoni kultural. ${ }^{14}$ Dengan kata lain, hegemoni diperoleh lewat perebutan, bukan pemberian. Bahkan hegemoni juga terus menerus diperjuangkan dan dinegosiasi ulang.

Proses hegemoni kultural tersebut mirip dengan model encoding (cara produksi makna) yang diperkenalkan Stuart Hall, bahwa produksi pesan bermakna dalam wacana media di-encoding melalui lebih dari satu cara. ${ }^{15}$ Karenanya, kajian terhadap wacana media berkenaan dengan bagaimana dan mengapa praktik produksi tertentu cenderung menghasilkan pesan tertentu yang serupa, yang mewujudkan maknanya dalam beragam bentuk yang berulang-ulang.

Dengan demikian, seperti yang dinyatakan Hall, televisi 
merupakan bagian dari prakondisi dan konstruksi selektif pengetahuan sosial, sebagai imajinasi sosial yang digunakan untuk memersepsi dan merekonstruksi realitas sosial. Sehingga konstruksi tersebut seolaholah menjadi semacam keseluruhan realitas yang masuk akal bagi masyarakat. ${ }^{16}$ Karenanya, tayangan televisi bukanlah jendela dunia yang langsung diterima begitu saja, tapi merupakan representasi terseleksi yang turut membentuk realitas sosial. Ini sebab pemilihan dan pemilahan segala hal yang dimasukkan pada tayangan televisi, dalam mengonstruksi pengetahuan, tak pernah netral.

Dari sinilah, sebagai tayangan yang paling banyak diminati masyarakat, dengan menggunakan teknologi canggih dalam mengekplorasi efek visual, film menjadi sarana paling efektif dalam menyebarkan wacana konstruktif dan paling sukses merekonstruksi identitas melalui berbagai representasi selektif. Karena itulah kita harus menyikapinya secara kritis saat terdapat praktik yang mengarah kepada hegemoni kultural.

\section{Metodologi Konstruksionisme Sosial}

Dalam kajian sosial dan budaya, konstruksionisme sosial merupakan istilah umum yang melingkupi sederet teori dengan beragam perspektif. Begitu beragamnya jumlah teori-teori tersebut sehingga menyulitkan penguraian yang bisa mencakup semua pendekatan ini. Namun kebanyakan konstruksionis sosial memandang relitas sosial merupakan bidang yang lebih teratur dalam situasi-situasi khusus. ${ }^{17}$ Situasi-situasi tersebut menghasilkan batasan-batasan tertentu terhadap identitas, peran atau sikap yang bisa diterima sebagai sesuatu yang bermakna.

Mengutip Stuart Hall, Eriyanto menyatakan bahwa realitas sosial tidaklah secara sederhana dapat dilihat sebagai bentuk kehidupan sebagaimana adanya, tetapi lebih merupakan hasil dari produksi ideologi atau pandangan tertentu. ${ }^{18}$ Begitu pula pandangan tentang identitas yang dihasilkan secara selektif melalui konstruksi wacana dan diproduksi terus-menerus dari realitas yang direpresentasikan. Dari fenomena itulah media mengonstruksi makna yang disesuaikan dengan kebutuhan penonton untuk memaknai realitas sosial. ${ }^{19}$ Karenanya, media berfungsi untuk menjaga, mengembangkan dan 
menyebarkan wacana tertentu sehingga terus dipertahankan dalam masyarakat. Implikasinya, makna yang muncul hanyalah makna yang ditranformasikan melalui bahasa.

Meski begitu banyak dan beragamnya teori-teori dalam lingkup konstruksionisme sosial, namun setidaknya, seperti yang ditulis Marianne W. Jorgesten dan Louise J. Pilips, dengan mengutip tulisan Vivien Burr, terdapat empat premis yang dimiliki semua pendekatan konstruksionis. Premis-premis tersebut adalah sebagai berikut: ${ }^{20}$

Pendekatan kritis pada konstruksi pengetahuan yang dianggap lumrah. Artinya, pengetahuan bukanlah gambaran murni dari kehidupan sosial, namun lebih merupakan produk wacana. Ini karena realitas hanya bisa diakses melalui kategori-kategori yang direpresentasikan dalam wacana.

Kekhususan kultural dan historis. Artinya, manusia adalah produk kultural dan historis. Pengetahuan tentang realitas sosial merupakan pertukaran-pertukaran antarindividu dalam konteks historis. Karenanya, pandangan terhadap identitas bisa berbeda dan berubah sepanjang waktu.

Hubungan antara pengetahuan dan proses sosial. Artinya, pengetahuan diciptakan melalui interaksi sosial, sebagai tempat dikonstruksinya makna bersama. Karenanya, pemahaman tentang realitas sosial diciptakan dan dipertahankan oleh proses sosial.

Hubungan antara pengetahuan dan tindakan sosial. Artinya, pemahaman yang berbeda tentang realitas sosial menggiring ke arah tindakan-tindakan sosial yang berbeda. Di sinilah konsekuensi politis dari wacana.

Meski demikian, karena premis-premis dalam konstruksionisme sosial begitu kompleks dan rumit, penelitian yang dilakukan penulis tak akan memuat dan menelusuri premis-premis tersebut, tapi terfokus pada pendekatan kritis terhadap konstruksi wacana yang dianggap lumrah tanpa menelusuri bagaimana proses awal terbentuk konstruksi wacana tersebut.

Kalau tujuan umum dari penelitian konstruksionis sosial adalah menyingkap konstruksi pengetahuan yang telah dinaturalisasikan, sebaliknya penelitian konstruksioniskritis bertujuan mendenaturalisasi pemahaman ideologis tentang realitas sosial. ${ }^{21}$ 
Dengan berpijak pada pemahaman bahwa representasi pengetahuan yang berbeda itu selalu mungkin bisa dilakukan, penelitian konstruksionis kritis mencoba menawarkan pemahamanpemahaman alternatif tentang realitas sosial. Sesuatu yang dianggap lumrah itu selalu membatasi kemungkinan untuk berpikir dan bertindak. Karenanya, sejumlah pemahaman alternatifbisa membantu setiap orang meninjau ulang pemahamannya untuk kemudian menentukan apa yang dianggap lebih baik.

Dengan demikian, semua pernyataan terbuka bagi pembahasan dan dapat dilanjutkan dengan perdebatan yang lebih demokratis. Dari sinilah kritik menjadi tujuan penelitian konstruksionis sosial, yaitu mengungkap klaim-klaim pemahaman yang tanpa didasari peninjauan terhadap beragam konsekuensi politis dan ideologis yang dikandungnya.

\section{Analisis Wacana Laclau dan Mouffe}

Analisis wacana merupakan salah satu jenis penelitian yang banyak digunakan dalam konstruksionisme sosial. ${ }^{22}$ Wacana terkait dengan praktik representasi sebagai cara suatu obyek diperbincangkan secara terbuka kepada dan oleh publik, sehingga menimbulkan pemahaman tertentu yang tersebar luas. ${ }^{23}$ Karenanya, wacana tak hanya merupakan cara pandang tertentu yang disajikan oleh media, tapi juga dapat menjadi acuan pemahaman yang siap diterapkan dalam kehidupan sosial.

Dalam menganalisis representasi perempuan dalam wacana film bernuansa Islami, metode analisis dalam tulisan ini menggunakan konsep wacana yang dikembangkan oleh Laclau dan Mouffe, tentunya setelah dipadukan dengan beberapa analisis wacana lainnya sesuai dengan kebutuhan penelitian. Dalam konsep teoritis mereka, wacana dipahami sebagai penetapan makna dalam domain tertentu. Menurut mereka, terdapat beberapa konsep yang melatari terbentuknya sebuah wacana: nodalpoints (titik nodal), necessary moments (tanda bermakna), contingent elements (unsur kemungkinan), field of discursivity (medan kewacanaan), dan articulatory practice (praktik artikulasi.) ${ }^{24}$

Titik nodal merupakan tanda yang memiliki hak khusus sebagai tempat menata tanda-tanda lain di sekitarnya. Tanda-tanda lain 
tersebut memeroleh maknanya dari hubungannya dengan titik nodal. Dengan kata lain, penataan tanda tersebut dilakukan dengan cara menyingkirkan semua kemungkinan makna lain dari penataan tandatanda yang berbeda. Semua kemungkinan yang disingkirkan dan berada di luar jejaring wacana tersebut disebut medan kewacanaan. ${ }^{25}$

Momen-momen adalah semua tanda yang terdapat dalam suatu wacana dan saling terkait. Momen-momen merupakan matajaringmatajaring yang maknanya ditetapkan dari perbedaan posisinya yang saling terkait. ${ }^{26}$ Makna tanda-tanda tersebut ditetapkan secara parsial di sekitar titik nodal. Karenanya, makna setiap tanda ditentukan oleh hubungan atau kaitannya dengan tanda-tanda lainnya, yang kemudian membentuk jejaring pemaknaan.

Oleh karena suatu wacana selalu disusun berdasarkan kaitannya dengan sesuatu yang berasal dari luar. Wacana berada dalam kondisi yang rentan retak atau dirusak oleh cara-cara lain yang digunakan untuk menetapkan maknanya. Di sini, konsep unsur dalam wacana menjadi relevan. Unsur adalah tanda yang maknanya belum tetap, yaitu tanda yang memiliki potensi makna ganda (polisemi) ${ }^{27}$ Dengan kata lain, wacana berusaha menransformasikan unsur-unsur ke dalam momen-momen dengan cara mengurangi poliseminya hingga menjadi makna yang sepenuhnya tetap, yaitu melalui praktik artikulasi.

Laclau dan Mouffe mendefinisikan artikulasi sebagai setiap praktik yang berusaha menetapkan hubungan antara unsur-unsur sedemikian rupa sehingga identitasnya dimodifikasi. ${ }^{28}$ Karenanya, suatu wacana selalu menetapkan pengakhiran atau hentian sementara pada fluktuasi-fluktuasi yang terdapat pada makna tanda-tanda. Meski pengakhiran tersebut tak pernah stabil dan tertutup.

Melalui praktik artikulasi itulah hegemoni makna terwujud. Menurut Laclau dan Mouffe, hegemoni terbentuk melalui praktik penggabungan beragam identitas, beserta kekuatan politisnya, untuk membangun tatanan sosial baru dalam sebuah proyek umum. ${ }^{29}$ Dari praktik artikulasi itulah hegemoni berupaya menyingkirkan keberagaman dengan menempatkannya dalam lingkup pemaknaan tatanan sosial baru yang dianggap niscaya terjadi.

Dalam penelitian ini, penulis menganalisis wacana perempuan Muslim dalam tiga tahap. Pertama, penulis merangkai jejaring 
pemaknaan (artikulasi) dalam alur cerita yang ditampilkan oleh masing-masing film bernuansa Islami, dengan berasumsi bahwa setiap film memiliki caranya masing-masing dalam memaknai perempuan. Karenanya, tanda-tanda yang dikonstruksi sebagai pemaknaan perempuan juga berbeda. Dengan menganalisis konstruksi makna pada setiap film, penulis mencoba menghindari generalisasi praktik pemaknaan terhadap perempuan, sebab praktik pemaknaan selalu terjadi dalam ruang spesifik dengan pola interaksinya tersendiri.

Kedua, setelah menemukan konstruksi makna perempuan pada setiap film, penulis mencoba membandingkan pola interaksi pada masing-masing film untuk menemukan kecenderungan pemaknaan yang sama dalam menghasilkan wacana perempuan. Langkah ini dilakukan untuk meninjau apakah terdapat praktik pemaknaan yang mengarah pada pola atau corak makna yang serupa, terutama pada representasi beragam posisi perempuan. Meski praktik pemaknaan beroperasi secara berbeda sesuai dengan alur cerita dalam film, namun ideologi yang melandasi bagaimana sebuah jejaring pemaknaan terwujud dapat ditemukan dengan menelusuri persamaannya. Dari keserupaaan praktik pemaknaan inilah akan ditemukan konstruksi identitas dan peran perempuan yang disebarkan atau disosialisasikan oleh film bernuansa Islami. Karenanya, naturalisasi makna atau penghadiran terus menerus kepada masyarakat sangat mungkin membentuk hegemoni kultural dalam kehidupan sosial.

Terakhir, setelah menemukan persamaan pada jejaring pemaknaan perempuan, penulis mencoba mengritisi dan menguji konstruksi atau naturalisasi makna melalui perbandingan dengan wacana perempuan lainnya dalam perjalanan sejarah Islam. Dari perbandingan inilah dapat ditemukan wacana-wacana alternatif sehingga masyarakat diharapkan dapat terhindar dari konstruksi makna tertentu dengan konsekuensi ideologis dan politisnya.

\section{Perempuan dalam Wacana Keislaman}

Sebelum membahas hasil penelitian terhadap representasi perempuan dalam film bernuansa Islami, terlebih dahulu penulis akan menyajikan representasi perempuan Muslim dalam sejarah Islam, yang nantinya akan diperbandingkan sebagai wacana alternatif. 
Islam tak pernah memberikan konsep makna yang secara jelas dapat diterapkan dalam setiap ruang dan waktu. Akan tetapi, ia merupakan proses pemaknaan dinamis dalam konteks tertentu, yang seringkali memunculkan beragam penafsiran dan membentuk wacana tertentu. Begitu pula dengan praktik pemaknaan terhadap perempuan Muslim: seperti apakah perempuan Muslim direpresentasikan dan merepresentasikan dirinya dalam wacana keislaman? Meski begitu, banyaknya wacana yang tersebar dalam sejarah Islam tak memungkinkan untuk dibahas seluruhnya. Namun, di sini hanya akan dibahas representasi perempuan Muslim yang memiliki tempat istimewa dalam wacana keislaman dan anehnya tersingkir dari wacana film bernuansa Islami.

\section{Keluarga dan Sahabat Rasul}

Tokoh perempuan Muslim yang memiliki tempat paling istimewa dalam wacana keislaman adalah Khadījah. Selain sebagai istri pertama Rasulullah, ia merupakan pendukung utama dalam memerjuangkan misi Islam. Kemandirian ekonominya dan tawaran perkawinannya tanpa perantara wali laki-laki mencerminkan representasi perempuan yang kemudian menjadi teladan perempuan Muslim. Ia mendukung Rasulullah, menentramkan hatinya, dan meyakinkannya bahwa wahyu-wahyu yang diterima di gua Gunung Hirā bukanlah dari setan, tapi berasal dari Tuhan. ${ }^{30}$ Dengan kata lain, Khadījah merupakan sosok pelindung Muhammad saat berada dalam masa transisi menjadi Rasul.

Begitu pula dengan 'Â'isyah; sebagai teladan perempuan Muslim, ia aktif menyampaikan fatwa dengan meriwayatkan 1.210 hadis, meski hanya 242 hadis yang tercantum dalam koleksi-koleksi Bukhārī dan Muslim. ${ }^{31}$ Bahkan 'Á'isyah pernah bertentangan dengan pendapat Abū Hurayrah mengenai satu isu dan dengan Ibn 'Abbās mengenai isu lainnya, dan dalam dua kasus itu pandangan 'Â'isyah lebih diterima daripada pendapat kedua sahabat tersebut. Dengan kata lain, 'Ā'isyah merupakan sosok Muslim yang mandiri dalam menyampaikan padangan dan memiliki sikap tegas.

Kisah kepahlawanan pernah ditampilkan oleh Nusaybah bint $\mathrm{Ka}$ 'b, salah satu sahabat perempuan Rasulullah yang terlibat dalam 
peperangan kaum Muslim. Ketika mengambarkan perannya dalam Perang Uhud, ia mengatakan bahwa ketika ia menyaksikan kaum Muslim menghadapi kekalahan, "Aku mengambil posisi di dekat Nabi dan aku mulai bertarung dengan pedangku, dalam gerakan pertahanan di seputar Rasulullah... aku bertarung hingga terluka." 32

Sementara tokoh terkemuka lainnya yang menampilkan ketegasan adalah Sakinah bint Husayn, cucu perempuan Rasulullah. Ia menjadi terkenal saat memaksa suaminya yang ketiga, cucu lakilaki 'Utsmān b. 'Affān, untuk tidak mendekati perempuan lain. Ia menceraikan suaminya saat memergokinya bersama salah seorang jawārì-nya yang sah. Sakīnah membawa suaminya ke pengadilan dan berteriak kepadanya di depan hakim Madīnah, "Pandanglah aku sepuasmu hari ini, sebab kamu tidak akan pernah melihatku lagi!"33

\section{Jawārī (Budak Perempuan)}

Para ahli sejarah klasik, seperti al-Tabarì dan Ibn 'Atsīr, mengemukakan bahwa setelah perempuan bangsawan menghilang dari catatan sejarah, lima atau enam generasi setelahnya digantikan oleh para jawārī. Yang paling dikenal adalah Ghādir, jāriyah Khalifah al-Hādī; 'Ārib, jāriyah Khalifah al-Ma'mūn; Farīdah, jāriyah Khalifah al-Hādī; Farīdah, jāriyah Khalifah Hārūn al-Rasyīd; serta Faḍl dan Mạ̣būbah, jāriyah Khalifah al-Mutawakkil. ${ }^{34}$

Perempuan-perempuan tersebut sangat berbakat, memiliki keahlian musik dan syair, serta kecantikan. Namun kedudukan mereka sebagai budak membuat mereka berada dalam posisi sulit. Sejak saat itulah kaum perempuan tak lagi menjalankan peran lainnya kecuali sebagai penghibur.

\section{Ratu Muslim Nusantara}

Wacana keislaman di Asia Tenggara lebih dinamis dibandingkan dengan wilayah Timur Tengah, terutama di Indonesia sebagai negara yang bermasyarakat plural. Saat Islam masuk dan berkembang di Indonesia, kerajaan-kerajaan Islam bermunculan dan berkembang hampir di seluruh kepulauan Indonesia.

Dalam catatan sejarah, terdapat beberapa ratu terkenal yang menjalankan pemerintahan dengan bijaksana. Ini misalnya tertera 
dalam beberapa batu nisan, dengan tulisan nama-nama ratu, yang ditemukan di Aceh. Nana Nurliana Soeyono mencantumkan dalam tulisannya sederetan nama-nama ratu yang pernah memerintah di Aceh, yaitu Ratu Malikah Nur (1380 M.), Ratu Nahrasiyah (1428 M.), Sultanah Tajul Alam Safiatuddin Syah (1641-1675), Sultanah Nurul Alam Naqiatuddin Syah (1675-1678), Sultanah Inayatsyah Zakiatuddin Syah (1678-1688), dan Sultanah Kamalatsyah Zairatuddin Syah (1688-1699.) ${ }^{35}$ Selain itu, salah satu pemimpin armada Aceh adalah seorang perempuan yang berpangkat laksamana, yaitu Keumalahayati yang berhasil mengalahkan dua buah kapal Belanda yang dipimpin Cornelis dan Frederick de Houtman. ${ }^{36}$

Di Jawa juga pernah dikenal pemimpin perempuan. Salah satunya adalah ratu Kalinyamat yang memerintah Kalinyamat dan Jepara. ${ }^{37}$ Di masa pemerintahannya, Jepara berkembang menjadi bandar penting yang didatangi armada dagang lokal dan asing. Sementara di Sulawesi juga terdapat pemimpin perempuan, yaitu Siti Aisyah We Tenriolle (1856 M.) yang berkuasa di kerajan Tanette. ${ }^{38}$ Selain mengurus persoalan kenegaraan, ia juga menaruh perhatian besar pada kesusastraan.

\section{Film Bernuansa Islami}

Film Ayat-ayat Cinta menandai fase masuknya nuansa keislaman ke dalam dunia perfilman. Film ini mengangkat persoalan kelas menengah Islam Indonesia dalam memecahkan berbagai problem mereka. Keberhasilan film ini meraih 3,5 juta penonton membuat gelombang produksi film-film bernuansa Islami semakin banyak. ${ }^{39}$

Tingginya apresiasi masyarakat terhadap film-film bernuansa Islami menjadikan prospek jenis film ini semakin besar, yang tentu saja setelah dipadukan dengan unsur-unsur budaya yang beragam, baik dari budaya lokal maupun luar negeri.

Seiring dengan menguatnya prospek produksi film bernuansa Islami, kecenderungan untuk meninjau unsur-unsur keislaman yang ditampilkan dalam adegan-adegan film juga semakin menguat. Unsur-unsur keislaman tersebut tak hanya terkait dengan keyakinan terhadap Islam, tapi juga mengandung implikasi politis dan ideologis dalam kehidupan masyarakat. 


\section{Perempuan dalam Film Bernuansa Islami}

Dalam kajian sebelumnya, konstruksi sosial dipahami sebagai artikulasi tanda-tanda yang diimajinasikan dan diterapkan dalam konteks sosial tertentu. Praktik artikulasi tersebut terbentuk melalui kesinambungan antara teks dan konteks: teks selain mewujud dalam konteks, juga terlibat dalam mengonstruksi pemaknaan konteks; sementara konteks selain menjadi wadah penerapan teks, juga merupakan ajang persaingan beragam pemaknaan teks. Dengan kata lain, teks dan konteks menyatu dan saling membentuk dalam kehidupan sosial. Film menampilkan beragam konteks yang telah diencode dan dikonstruksi sebagai teks, yaitu melalui proses pemilahan dan pemilihan aspek-aspek tertentu, yang disesuaikan dengan atau disediakan untuk memunculkan atau menyosialisasikan artikulasi pemahaman tertentu.

Tulisan ini akan membahas hasil penelitian penulis tentang representasi perempuan yang dikonstruksi dalam lima film bernuansa Islami: Ayat-ayat Cinta (A2C), Perempuan Berkalung Sorban (PBS), Tiga Doa Tiga Cinta (3D3C), Laskar Pelangi (LP), dan Ketika Cinta Bertasbih (KCB.) Kelima film tersebut dianggap mewakili film-film bernuansa Islami lainnya. Alasannya, selain memiliki nuansa Islami yang sangat kental, kelima film tersebut merupakan film bernuansa Islami yang paling populer dan laris di Indonesia pada tahun 2009, baik berdasarkan membludaknya penonton bioskop maupun penerimaan penghargaan dari dalam dan luar negeri. Popularitas itulah yang menjadikan film tersebut berpotensi besar mengonstruksi wacana dan menyebarkan pandangan ideologis tanpa disadari oleh para penontonnya.

Selain itu, dari beragam tema dan alur yang tampilkan dalam film bernuansa Islami, penulis akan membatasi fokus kajian pada pola interaksi yang mengonstruksi dan merepresentasikan identitas dan peran perempuan Muslim. Dengan demikian, data-data yang akan diambil, sesuai dengan analisis wacana Laclau dan Mouffe, adalah data-data yang berkaitan dengan artikulasi jejaring pemaknaan perempuan yang mencolok dalam kelima film tersebut.

Karenanya, dalam mengumpulkan data, langkah pertama adalah menentukan pemeran perempuan Muslim yang paling 
banyak mewarnai alur cerita sebagai titik nodal. Lalu penulis akan mengaitkannya dengan posisi, peran dan sikap yang terbentuk dalam interaksi sosialnya, yang telah terkonstruksi dalam film. Posisi perempuan terkait dengan bagaimana perempuan ditempatkan dalam struktur sosialnya, misalnya sebagai istri, anak, sahabat atau kekasih. Posisi inilah yang akan membatasi ruang pemaknaan perempuan sekaligus memberikan landasan untuk analisis representasi selanjutnya.

Sementara peran dan sikap perempuan merupakan cara dan pola perempuan dikonstruksi dalam interaksi sosialnya, seperti patuh, membangkang, menentukan keputusan, mengatasi masalah dan sebagainya. Cara perempuan berperan dan bersikap itulah yang kemudian dikonstruksi dan dimaknai sebagai yang natural atau lumrah terjadi dalam realitas sosial.

Meski dalam film bernuansa Islami perempuan direpresentasikan dengan cara beragam, terdapat titik persamaan yang dapat ditarik dari pola interaksi yang kemudian mengonstruksi representasi perempuan. Dalam pola persamaan yang tersebar, wacana perempuan dikonstruksi dan berpotensi dianggap lumrah: semua perempuan selalu berperan dan bersikap seperti itu. Seolah kita tak memiliki referensi lain tentang perempuan dan menganggap perempuan tercipta selalu dan seharusnya seperti yang disajikan dalam film-film tersebut. Karena itulah sebuah wacana menyimpan implikasi politis: perempuan sering diarahkan pada posisi dan peran yang sering tak menguntungkan mereka. Naturalisasi makna tersebut kemudian berujung pada hegemoni kultural.

\section{Representasi Perempuan sebagai Ibu}

Posisi ibu selalu melekat pada sosok perempuan, begitu pula dalam film bernuansa Islami. Mungkin disebabkan begitu pentingnya sosok ibu dalam agama Islam, hingga semua film yang diteliti memasukkan sosok ibu dalam ceritanya.

Tabel 1. Sikap Aktor Perempuan sebagai Ibu terhadap Anaknya

\begin{tabular}{|c|c|l|l|}
\hline No & Perempuan & \multicolumn{1}{|c|}{ Konstruksi Sosial } & \multicolumn{1}{c|}{ Pola Interaksi } \\
\hline 1. & $\begin{array}{c}\text { Ibu Fahri } \\
\text { (A2C) }\end{array}$ & $\begin{array}{l}\text { Percakapan melalui telepon } \\
\text { antara Fahri di Mesir dan } \\
\text { ibunya di Indonesia }\end{array}$ & $\begin{array}{l}\text { Menasehati Fahri untuk } \\
\text { segera mencari calon istri } \\
\text { dan menikah }\end{array}$ \\
\hline
\end{tabular}




\begin{tabular}{|c|c|c|c|}
\hline & & $\begin{array}{l}\text { Percakapan melalui telepon } \\
\text { antara ibu Fahri dan Aisyah } \\
\text { setelah Fahri di penjara }\end{array}$ & $\begin{array}{l}\text { Menangis dan menyatakan } \\
\text { bahwa Fahri difitnah, tak } \\
\text { mungkin memerkosa }\end{array}$ \\
\hline 2. & $\begin{array}{l}\text { Ibu Maria } \\
\text { (A2C) }\end{array}$ & $\begin{array}{l}\text { Maria kehilangan gairah } \\
\text { hidup setelah tahu Fahri } \\
\text { menikah }\end{array}$ & $\begin{array}{l}\text { Menemani dan menghibur } \\
\text { Maria }\end{array}$ \\
\hline \multirow[t]{4}{*}{3.} & \multirow[t]{4}{*}{$\begin{array}{l}\text { Ibu Anisa } \\
\text { (PBS) }\end{array}$} & $\begin{array}{l}\text { Anisa bermain di luar den- } \\
\text { gan menunggang kuda }\end{array}$ & $\begin{array}{l}\text { Memanggil Anisa dan } \\
\text { menyatakan bahwa anak } \\
\text { perempuan tak boleh } \\
\text { menunggang kuda }\end{array}$ \\
\hline & & Makan malam keluarga & Menyiapkan makanan \\
\hline & & $\begin{array}{l}\text { Syamsudin menuduh Anisa } \\
\text { dan Khadari berzina dan } \\
\text { penghuni pesantren mele- } \\
\text { mpari mereka dengan batu }\end{array}$ & $\begin{array}{l}\text { Berteriak keras untuk } \\
\text { menghentikan perbuatan } \\
\text { penghuni pesantren }\end{array}$ \\
\hline & & $\begin{array}{l}\text { Anisa dan saudaranya berde- } \\
\text { bat dan saling membentak }\end{array}$ & $\begin{array}{l}\text { Menghentikan pertikaian } \\
\text { mereka bahwa itu tak pan- } \\
\text { tas terjadi di pesantren }\end{array}$ \\
\hline 4. & $\begin{array}{l}\text { Ibu Ikal } \\
\text { (LP) }\end{array}$ & $\begin{array}{l}\text { Pagi-pagi, suaminya berang- } \\
\text { kat kerja, sementara Ikal } \\
\text { berangkat sekolah }\end{array}$ & $\begin{array}{l}\text { Menyiapkan makanan dan } \\
\text { menyetrika pakaian }\end{array}$ \\
\hline 5. & $\begin{array}{l}\text { Ibu Azzam } \\
\text { (KCB) }\end{array}$ & $\begin{array}{l}\text { Azzam pulang dari Mesir } \\
\text { setelah menyelesaikan kuliah }\end{array}$ & $\begin{array}{l}\text { Menyiapkan makanan } \\
\text { Mendesak Azzam menikah }\end{array}$ \\
\hline 6. & $\begin{array}{l}\text { Ibu Ana } \\
(\mathrm{KCB})\end{array}$ & $\begin{array}{l}\text { Ana bingung menentukan } \\
\text { siapa yang akan menjadi } \\
\text { calon suaminya }\end{array}$ & $\begin{array}{l}\text { Menyiapkan makanan dan } \\
\text { menghibur Ana }\end{array}$ \\
\hline
\end{tabular}

Sosok ibu selalu direpresentasi selaras, meski dengan pola berbeda, dan membentuk kesamaan peran dan sikap. Ibu Anisa, ibu Ikal dan Ibu Azzam pernah disorot sedang mengurusi urusan rumah tangga seperti memasak, menyetrika dan menyiapkan makanan. Dan meski ibu-ibu lainnya tak pernah disorot sedang mengerjakan urusan rumah tangga, namun hampir semua ibu direpresentasikan berada dekat dengan rumah. Hanya Ibu Maria yang merawat Maria di rumah sakit karena pekerjaannya memang sebagai dokter di rumah sakit itu.

Persamaan lainnya adalah perhatian mendalam semua ibu terhadap anaknya. Semua ibu direpresentasikan sangat memerhatikan dan menyayangi anaknya, baik anak laki-laki maupun perempuan, 
baik berhubungan langsung maupun dari jarak jauh. Perhatian yang paling mencolok adalah memastikan anaknya memiliki pasangan hidup. Bahkan ibu Anisa menjadi satu-satunya pembela yang gigih saat anaknya dikasari para penghuni pesantren.

Dengan demikian, seorang ibu hanya direpresentasikan berurusan dengan pekerjaan rumah tangga dan memiliki hubungan emosional yang kuat dengan anaknya. Dalam hal inilah makna perempuan sebagai ibu dinaturalisasikan: tak perlu mencari pekerjaan ke luar rumah, apalagi ikut campur dengan pekerjaan suaminya, dan memiliki tugas utama memerhatikan perkembangan anak. Demikian 'menjadi ibu yang baik' yang diwacanakan atau disebarkan oleh beragam film bernuansa Islami.

\section{Representasi Perempuan sebagai Istri}

Seperti halnya posisi sebagai ibu, posisi istri yang direpresentasikan film bernuansa Islami memiliki banyak kemiripan. Semua film bernuansa Islami memberikan peran yang sama terhadap seorang istri, hanya terdapat perbedaan sikap dalam latar yang berbeda.

Tabel 2. Sikap Aktor Perempuan sebagai Istri

\begin{tabular}{|c|c|l|l|}
\hline No & Perempuan & \multicolumn{1}{|c|}{ Konstruksi Sosial } & \multicolumn{1}{|c|}{ Pola Interaksi } \\
\hline 1. & $\begin{array}{c}\text { Aisyah } \\
\text { (A2C) }\end{array}$ & $\begin{array}{l}\text { Fahri terlihat bercanda dan } \\
\text { bermesraan dengan Maria }\end{array}$ & $\begin{array}{l}\text { Dia menjaga jarak dengan } \\
\text { Fahri dan Maria karena } \\
\text { cemburu, bahkan pergi } \\
\text { dari rumah hingga Fahri } \\
\text { menjemputnya, lalu beru- } \\
\text { saha bersikap akrab kepada } \\
\text { Maria }\end{array}$ \\
\hline 2. & $\begin{array}{l}\text { Maria } \\
\text { (A2C) }\end{array}$ & $\begin{array}{l}\text { Saat Maria ngobrol dengan } \\
\text { Fahri, Aisyah mondar-man- } \\
\text { dir dan terjatuh }\end{array}$ & $\begin{array}{l}\text { Setelah menyadari kesa- } \\
\text { lahannya, dia minta maaf } \\
\text { kepada Fahri dan Aisyah, } \\
\text { lalu penyakitnya kambuh } \\
\text { dan meninggal }\end{array}$ \\
\hline 3. & Anisa & $\begin{array}{l}\text { Sebagai suami jahat, Syam- } \\
\text { sudin sering membentak dan } \\
\text { berbuat kasar kepadanya }\end{array}$ & $\begin{array}{l}\text { Dia sering bertikai dengan } \\
\text { Syamsudin meski tetap } \\
\text { melayaninya }\end{array}$ \\
\cline { 3 - 5 } & (PBS) & $\begin{array}{l}\text { Sebagai suami baik, Kha- } \\
\text { dari sering membantu dan } \\
\text { menasehatinya }\end{array}$ & $\begin{array}{l}\text { Dia sering bertukar pen- } \\
\text { dapat dengan Khadari dan } \\
\text { mengikuti anjurannya }\end{array}$ \\
\hline
\end{tabular}




\begin{tabular}{|c|c|l|l|}
\hline 4. & $\begin{array}{c}\text { Istri Kiai } \\
(3 \mathrm{D} 3 \mathrm{C})\end{array}$ & $\begin{array}{l}\text { Suaminya berdoa sebelum } \\
\text { bersetubuh }\end{array}$ & $\begin{array}{l}\text { Sambil terlentang di atas } \\
\text { ranjang, dia menunggu } \\
\text { suami berdoa }\end{array}$ \\
\hline 5. & $\begin{array}{c}\text { Istri Huda } \\
(3 \mathrm{D} 3 \mathrm{C})\end{array}$ & $\begin{array}{l}\text { Huda sedang membaca kitab } \\
\text { di ruang tamu }\end{array}$ & $\begin{array}{l}\text { Dia memberi minuman } \\
\text { kepada Huda }\end{array}$ \\
\hline 6. & $\begin{array}{c}\text { Ana } \\
(\mathrm{KCB})\end{array}$ & $\begin{array}{l}\text { Furqan mengaku sedang } \\
\text { mengidap HIV }\end{array}$ & $\begin{array}{l}\text { Dia marah besar dan mera- } \\
\text { sa Furqan telah menipunya }\end{array}$ \\
\hline
\end{tabular}

Semua istri dalam film direpresentasikan berperan mendampingi dan melayani suami, baik suami yang baik maupun yang jahat. Perbedaan hanya terdapat dalam sikap istri terhadap suami yang jahat. Misalnya Anisa yang selalu membantah suami pertamanya yang sering berbuat kasar. Meski demikian, dia tetap melaksanakan tugasnya melayani suami. Selain fenomena tersebut, istri selalu menuruti cara hidup suaminya. Hal itu dibuktikan dengan banyaknya keputusan rumah tangga yang dipegang oleh suami. Dengan kata lain, istri dianggap seharusnya mematuhi suami selama suaminya berbuat baik.

Namun yang menarik, terdapat persamaan ketegantungan emosional yang dialami istri terhadap suaminya. Aisyah selalu cemburu saat suaminya dekat dengan istri keduanya (Maria); begitu pula Maria yang penyakitnya kambuh lagi hingga membawanya pada kematian. Kesedihan mendalam juga dialami Anisa saat suaminya meninggal. Anisa bahkan sempat hilang ingatan dan terisak histeris. Hanya Ana yang berani meminta dicerai.

Dengan demikian, seorang istri tak hanya direpresentasikan bertugas mematuhi suami, tapi dia juga disudutkan sebagai orang yang lebih lemah secara emosional daripada suaminya. Karenanya, perempuan yang mudah terhanyut dalam kesedihan atau tak mampu mengendalikan emosinya sangat mungkin dianggap lumrah dan lazim memmenuhi kodratnya sebagai wanita.

\section{Representasi Perempuan sebagai Anak}

Berbeda dari kedua posisi sebelumnya, posisi sebagai anak perempuan memiliki perbedaan representasi yang mencolok. Dan tak banyak film bernuansa Islami yang mengisahkan anak perempuan dalam alur ceritanya. 
Tabel 3. Sikap Aktor Perempuan sebagai Anak

\begin{tabular}{|c|c|l|l|}
\hline No & Perempuan & \multicolumn{1}{|c|}{ Konstruksi Sosial } & \multicolumn{1}{|c|}{ Pola Interaksi } \\
\hline 1. & $\begin{array}{c}\text { Nauroh } \\
(\text { A2C })\end{array}$ & $\begin{array}{l}\text { Ayah tirinya sering mem- } \\
\text { bentak dan memukulnya }\end{array}$ & $\begin{array}{l}\text { Dia hanya bisa menangis } \\
\text { dan mengharap perto- } \\
\text { longan }\end{array}$ \\
\hline 2. & $\begin{array}{c}\text { Anisa } \\
\text { (PBS) }\end{array}$ & $\begin{array}{l}\text { Ayahnya sering memarahi } \\
\text { sambil mengajarinya prilaku } \\
\text { sebagai perempuan }\end{array}$ & $\begin{array}{l}\text { Dia menentang ajaran } \\
\text { ayahnya dan tradisi pe- } \\
\text { santren }\end{array}$ \\
\hline 3. & $\begin{array}{c}\text { Ana } \\
\text { (KCB) }\end{array}$ & $\begin{array}{l}\text { Kedua orangtuanya mende- } \\
\text { saknya untuk menikah }\end{array}$ & $\begin{array}{l}\text { Dengan sopan, dia menya- } \\
\text { takan belum menemukan } \\
\text { pasangan tepat }\end{array}$ \\
\hline
\end{tabular}

Seorang anak perempuan direpresentasikan secara berbeda. Nauroh adalah anak yang tak mampu berbuat apa-apa saat dikasari oleh ayah tirinya, bahkan membantah pun tak bisa. Dia hanya bisa pasrah dalam kesedihan, dan berbeda dari Anisa yang selalu menentang pendapat dan ajaran ayahnya yang selalu merendahkan perempuan. Bahkan setelah dihukum, Ana tetap menggugat ayahnya dengan lantang. Sementara Ana, sebagai anak terpelajar yang memiliki orang tua baik, dengan sopan menanggapi desakan orang tuanya.

Dengan demikian, perbedaan sikap anak perempuan yang direpresentasikan film bernuansa Islami mampu menghindari praktik naturalisasi, karena berbagai film tak menampilkannya secara beragam. Dengan kata lain, menjadi seorang anak dapat memiliki sikap beragam sesuai dengan konteks yang melatarinya.

\section{Representasi Perempuan sebagai Sahabat}

Perempuan yang diposisikan sebagai sahabat dalam film bernuansa Islami dapat dibagi berdasarkan dua latar berbeda: persahabatan orang dewasa dan persahabatan anak-anak. Persahabatan anak-anak hanya terdapat dalam satu film, Laskar Pelangi.

Tabel 4. Sikap Aktor Perempuan sebagai Sahabat

\begin{tabular}{|c|c|c|c|}
\hline No & Perempuan & Konstruksi Sosial & Pola Interaksi \\
\hline 1. & $\begin{array}{l}\text { Maria } \\
(\text { AAC) }\end{array}$ & $\begin{array}{l}\text { Fahri meminta bantuannya } \\
\text { memeriksa komputer, dan } \\
\text { bingung saat tahu proposal } \\
\text { tesisnya rusak terkena virus }\end{array}$ & $\begin{array}{l}\text { Dia membantu Fahri memer- } \\
\text { iksa komputernya, berinisi- } \\
\text { atif menggarap tesis bersa- } \\
\text { ma-sama, dan memuja Fahri }\end{array}$ \\
\hline
\end{tabular}




\begin{tabular}{|c|c|c|c|}
\hline & & Fahri menikahi Aisyah & $\begin{array}{l}\text { Dia menangis dan tak men- } \\
\text { jawab sapaan Fahri }\end{array}$ \\
\hline \multirow[t]{2}{*}{2.} & \multirow[t]{2}{*}{$\begin{array}{l}\text { Nurul } \\
(\mathrm{A} 2 \mathrm{C})\end{array}$} & $\begin{array}{l}\text { Fahri memimpin rapat or- } \\
\text { ganisasi yang diikutinya }\end{array}$ & $\begin{array}{l}\text { Dia memuji Fahri, diam-di- } \\
\text { am mengambil foto Fahri } \\
\text { dan menempelkan di buku } \\
\text { harian }\end{array}$ \\
\hline & & Fahri menikahi Aisyah & $\begin{array}{l}\text { Dia menangis terisak, } \\
\text { bersikap dingin dan tak men- } \\
\text { jawab sapaan Fahri }\end{array}$ \\
\hline \multirow[t]{2}{*}{3.} & \multirow[t]{2}{*}{$\begin{array}{l}\text { Naurah } \\
(\mathrm{A} 2 \mathrm{C})\end{array}$} & $\begin{array}{l}\text { Fahri pernah membantu } \\
\text { mengemasi barang-barang- } \\
\text { nya yang terjatuh }\end{array}$ & $\begin{array}{l}\text { Dia menyerahkan surat cin- } \\
\text { ta kepada Fahri dan sering } \\
\text { memandanginya dari jendela }\end{array}$ \\
\hline & & $\begin{array}{l}\text { Setelah Fahri menikah, dia } \\
\text { pernah diperkosa Bahadur }\end{array}$ & $\begin{array}{l}\text { Dia memfitnah Fahri telah } \\
\text { memerkosanya }\end{array}$ \\
\hline 4. & $\begin{array}{l}\text { Anisa } \\
(\mathrm{PBS})\end{array}$ & $\begin{array}{l}\text { Khadari, paman sekaligus } \\
\text { sahabat satu-satunya yang } \\
\text { peduli padanya, baru pulang } \\
\text { dari Mesir }\end{array}$ & $\begin{array}{l}\text { Dia menangis dan mengajak } \\
\text { Khadari pergi dan keluar } \\
\text { dari bentuk kekerasan yang } \\
\text { diterimanya }\end{array}$ \\
\hline \multirow[t]{2}{*}{5.} & \multirow[t]{2}{*}{$\begin{array}{l}\text { Sahara } \\
\text { (LP) }\end{array}$} & $\begin{array}{l}\text { Ada siswa idiot bernama } \\
\text { Harun di sekolah }\end{array}$ & $\begin{array}{l}\text { Dia sering menemani dan } \\
\text { mengajari Harun }\end{array}$ \\
\hline & & $\begin{array}{l}\text { Flo dan Mahar mengajak sa- } \\
\text { habat-sahabatnya menemui } \\
\text { Tuk Bayantula }\end{array}$ & $\begin{array}{l}\text { Dia menolak dan menya- } \\
\text { takan bahwa itu perbuatan } \\
\text { syirik }\end{array}$ \\
\hline 6. & $\begin{array}{l}\text { Flo } \\
(\mathrm{LP})\end{array}$ & $\begin{array}{l}\text { Di kampungnya terdapat to- } \\
\text { koh mistik terkenal bernama } \\
\text { Tuk Bayantula }\end{array}$ & $\begin{array}{l}\text { Dia berinisiatif mengajak } \\
\text { sahabat-sahabatnya bertemu } \\
\text { Tuk Bayantula }\end{array}$ \\
\hline 7. & $\begin{array}{l}\text { Eliana } \\
(\mathrm{KCB})\end{array}$ & $\begin{array}{l}\text { Sebagai anak duta besar, } \\
\text { dia sibuk memersiapkan } \\
\text { pelbagai acara, termasuk } \\
\text { penyediaan makanan tamu }\end{array}$ & $\begin{array}{l}\text { Dia meminta Azzam mem- } \\
\text { buat makanan untuk aca- } \\
\text { ra-acaranya, dan suatu saat } \\
\text { dia mengagumi prinsip yang } \\
\text { dipegang Azzam }\end{array}$ \\
\hline \multirow[t]{2}{*}{8.} & \multirow[t]{2}{*}{$\begin{array}{l}\text { Ana } \\
(\mathrm{KCB})\end{array}$} & $\begin{array}{l}\text { Dalam perjalanan dia bigung } \\
\text { mencari lokasi. Kebetulan } \\
\text { Azzam duduk di sebelahnya }\end{array}$ & $\begin{array}{l}\text { Dia menyapa dan menan- } \\
\text { yakan lokasi yang ditujunya } \\
\text { kepada Azzam }\end{array}$ \\
\hline & & $\begin{array}{l}\text { Dalam perjalanan pulang } \\
\text { sahabatnya kecopetan dan } \\
\text { buku-bukunya terbawa bus }\end{array}$ & $\begin{array}{l}\text { Dia menenangkan sahabatn- } \\
\text { ya dan Azzam datang mem- } \\
\text { bantu menemukan busnya. } \\
\text { Sebelum pergi, dia menan- } \\
\text { yakan nama Azzam }\end{array}$ \\
\hline
\end{tabular}




\begin{tabular}{|c|c|l|l|}
\hline 9. & $\begin{array}{c}\text { Tiara } \\
\text { (KCB) }\end{array}$ & $\begin{array}{l}\text { Orangtuanya menjodohkan- } \\
\text { nya dengan laki-laki yang } \\
\text { tidak disukainya, sementara } \\
\text { dia mencintai Fadhil }\end{array}$ & $\begin{array}{l}\text { Dia menangis dan mendesak } \\
\text { Cut Mala, sahabat akrab } \\
\text { sekaligus adik Fadhil, supaya } \\
\text { Fadhil segera melamarnya, } \\
\text { namun Fadhil belum siap }\end{array}$ \\
\hline 10. & $\begin{array}{c}\text { Italiana } \\
(\text { KCB })\end{array}$ & $\begin{array}{l}\text { Furqan pernah berkenalan } \\
\text { dengannya }\end{array}$ & $\begin{array}{l}\text { Dia menelpon, menipu dan } \\
\text { memeras Furqan }\end{array}$ \\
\hline
\end{tabular}

Dari tabel di atas, dapat terlihat bahwa persahabatan orang dewasa selalu berujung pada kisah percintaan. Maria, Nurul, Nauroh, Anisa dan Tiara adalah perempuan yang memuja laki-laki idamannya. Tak hanya memuja, di ujung cerita mereka menampakkan ketergantungan emosional kepada laki-laki yang dipujanya. Seolah laki-laki itulah yang menentukan kebahagiaan dan kesedihan dalam kehidupan mereka. Perbedaannya hanya terdapat pada sikap mereka saat tak dipilih oleh laki-laki pujaannya. Perempuan tak terpelajar yang diperankan oleh Nauroh meluapkan rasa kesalnya dengan cara memfitnah. Sedangkan perempuan terpelajar yang diperankan Nurul, Maria, Anisa dan Tiara meluapkannya dengan cara menangis histeris. Namun beragam cara yang mereka tunjukkan sama-sama mengacu pada ketergantungan emosional. Hanya Ana dan Eliana yang tak menampakkan ketergantungan emosional. Dengan demikian, praktik naturalisasi pun terjadi dalam representasi persahabatan orang dewasa.

Berbeda dari persahabatan anak-anak yang direpresentasikan secara beragam, Sahara adalah anak baik yang patuh pada ajaran agama dan selalu menasehati sahabat-sahabatnya. Sedangkan Flo adalah anak nakal yang percaya pada hal-hal mistis dan bahkan mengajak sahabatsahabatnya menemui dukun. Karenanya, representasi persahabatan anakanak terhindar dari praktik naturalisasi. Meski kita masih bisa menarik pembedaan antara anak baik dan anak nakal, tapi tak ada naturalisasi gender di sana.

\section{Representasi Perempuan sebagai Mahasiswi}

Posisi perempuan sebagai mahasiswi juga memiliki persamaan dan perbedaan representasi. Namun terdapat pola sikap yang beragam, mahasiswi juga terlibat aktif dalam berbagai kegiatan organisasi, 
meski terdapat perbedaan karakter yang dilekatkan pada mereka. Misalnya Nurul sebagai mahasiswi baik selalu mengingatkan sahabatsahabatnya untuk tidak berisik saat rapat. Sementara dua sahabatnya sering berisik dan suka bergosip. Begitu pula Anisa, selain belajar di kampus, dia juga sering menulis di berbagai media cetak. Sedangkan Ana pernah tampil sebagai moderator seminar dan pembanding pada acara bedah novel.

Tabel 5. Sikap Aktor Perempuan sebagai Mahasiswi

\begin{tabular}{|c|c|l|l|}
\hline No & Perempuan & \multicolumn{1}{|c|}{ Konstruksi Sosial } & \multicolumn{1}{|c|}{ Pola Interaksi } \\
\hline 1. & $\begin{array}{c}\text { Nurul } \\
\text { (A2C) }\end{array}$ & $\begin{array}{l}\text { Dalam rapat organisasi yang } \\
\text { dipimpin Fahri }\end{array}$ & $\begin{array}{l}\text { Dia menegur temannya } \\
\text { yang berisik }\end{array}$ \\
\hline 2. & $\begin{array}{c}\text { Dua sahabat } \\
\text { Nurul } \\
\text { (A2C) }\end{array}$ & $\begin{array}{l}\text { Dalam rapat organisasi yang } \\
\text { dipimpin Fahri }\end{array}$ & $\begin{array}{l}\text { Di tengah rapat, mereka } \\
\text { ngobrol dan menggosipi } \\
\text { Fahri }\end{array}$ \\
\hline 3. & $\begin{array}{c}\text { Anisa } \\
(\mathrm{PBS})\end{array}$ & $\begin{array}{l}\text { Dalam sebuah diskusi kelas } \\
\text { di Jogja }\end{array}$ & $\begin{array}{l}\text { Dia sering bertanya dan } \\
\text { di samping itu juga aktif } \\
\text { menulis tentang kebebasan }\end{array}$ \\
\hline 4. & $\begin{array}{c}\text { Ana } \\
\text { KCB })\end{array}$ & $\begin{array}{l}\text { Selain menyelesaikan tesis, } \\
\text { dia terlibat di pelbagai acara }\end{array}$ & $\begin{array}{l}\text { Dia menjadi moderator } \\
\text { seminar dan juga sebagai } \\
\text { pembanding bedah novel }\end{array}$ \\
\hline
\end{tabular}

Dengan demikian, representasi mahasiswi juga dapat terhindar dari praktik naturalisasi. Meski kita masih bisa menarik pembedaan antara mahasiswi yang baik dan yang kurang baik. Mahasiswi yang baik memiliki sifat-sifat tertentu yang berbeda dari mahasiswi yang kurang baik.

\section{Representasi Perempuan sebagai Guru}

Perempuan yang berperan sebagai guru juga direpresentasikan secara berbeda, meski hanya dua film yang memberikan kisah guru perempuan dalam alur ceritanya, kita dapat melihat adanya perbedaan antara guru yang baik dan yang buruk. Bu Muslimah direpresentasikan sebagai guru yang baik. Dia selalu memerhatikan dan membimbing murid-muridnya dengan cara lembut. Sementara guru yang buruk sering memarahi murid-muridnya jika berprilaku tak sesuai dengan yang diinginkannya dan bahkan membatasi kebebasan murid-muridnya. 
Dengan demikian, perempuan yang direpresentasikan sebagai guru tak mengalami praktik naturalisasi gender. Tabel berikut dapat memberikan gambaran tersebut.

Tabel 6. Sikap Aktor Perempuan sebagai Guru

\begin{tabular}{|c|c|l|l|}
\hline No & Perempuan & \multicolumn{1}{|c|}{ Konstruksi Sosial } & \multicolumn{1}{|c|}{ Pola Interaksi } \\
\hline 1. & $\begin{array}{c}\text { Guru } \\
\text { Pesantren } \\
(\mathrm{PBS})\end{array}$ & $\begin{array}{l}\text { Saat mengajar, seorang santri } \\
\text { cekikikan sambil membaca } \\
\text { buku }\end{array}$ & $\begin{array}{l}\text { Dia memarahi santri terse- } \\
\text { but dan membawanya ke } \\
\text { kantor }\end{array}$ \\
\hline 2. & $\begin{array}{c}\text { Muslimah } \\
(\mathrm{LP})\end{array}$ & $\begin{array}{l}\text { Sebagai pengajar di sekolah } \\
\text { miskin, bersama pak Harfan, } \\
\text { dia berhubungan dekat den- } \\
\text { gan murid-muridnya }\end{array}$ & $\begin{array}{l}\text { Dia selalu memerhatikan } \\
\text { dan membimbing mu- } \\
\text { rid-muridnya }\end{array}$ \\
\cline { 3 - 4 } & $\begin{array}{l}\text { Bakri menyatakan akan pin- } \\
\text { dah sekolah }\end{array}$ & $\begin{array}{l}\text { Dia menyesali ketak- } \\
\text { pedulian Bakri terhadap } \\
\text { satu-satunya sekolah untuk } \\
\text { anak miskin itu }\end{array}$ \\
\hline
\end{tabular}

\section{Perempuan dalam Ranah Domestik}

Dalam kehidupan rumahtangga, semua film yang menjadi sampel penelitian merekam peran ibu atau istri dalam alur ceritanya. Ayatayat Cinta termasuk film yang paling banyak merekam kehidupan rumah tangga. Peran ibu dalam film ini selalu berada di dalam rumah, hanya ibu Maria yang pernah berperan di ranah publik, yaitu di rumah sakit, karena dia bekerja sebagai dokter. Begitu pula Perempuan Berkalung Sorban, peran ibu dalam film ini selalu berada dalam rumah dan menasehati anaknya. Dua film lainnya, Laskar Pelangi dan 3 Doa 3 Cinta, pernah sekilas merekam kehidupan ibu. Ibu hanya berperan memasak dan menyiapkan makanan. Fenomena tersebut juga terdapat dalam film terakhir, Ketika Cinta Bertasbih. Para ibu selalu ditampilkan di rumah dengan pekerjaan konvensional.

Seperti halnya peran sebagai ibu, perempuan yang berperan sebagai istri tak lepas dari kehidupan rumahtangga. Dia selalu mendampingi dan mematuhi suaminya, secara suka rela maupun terpaksa. Misalnya Anisa, meski tak suka pad prilaku suami pertamanya, tetap tak bisa menentang dan harus melayani suaminya. Begitu pula istri-istri yang sekaligus berperan sebagai ibu, seperti ibu Ikal, ibu Anisa dan sebagainya. Hampir tak ada laki-laki yang 
ditampilkan melakukan pekerjaan rumahtangga selain Khadari yang pernah membantu istrinya memasak di dapur.

\section{Ketergantungan Emosional}

Hampir semua film yang diteliti diwarnai kisah cinta dalam alur ceritanya. Ayat-ayat Cinta merupakan film yang paling banyak memuat kisah cinta. Bermula dari persahabatan, perempuan dalam film ini lambat laun mengagumi laki-laki pujaannya, Fahri. Kekaguman mungkin masih bisa diterima. Namun tak hanya kagum, perempuan dalam film ini memujanya seolah dialah satu-satunya laki-laki yang mampu memberikan kebahagiaan. Hal itu nampak jelas saat Fahri menikah dengan Aisyah. Maria dan Nurul menangis histeris dan bersikap dingin saat bertemu Fahri. Bahkan kesedihan Maria membuat penyakitnya kambuh. Saat mengenang Fahri di sungai Nil, darah menetes dari hidung Maria. Setelah Fahri menikahi Maria karena didesak Aisyah yang merasa kasihan pada Maria, kedua perempuan itu selalu terbakar api cemburu. Kehidupan rumahtangga mereka tak pernah stabil. Hingga akhirnya Maria merasa bersalah dan meninggal. Dengan kata lain, film ini seolah-olah menunjukkan bahwa hanya kematianlah yang mampu membebaskan Maria dari ketergantungan emosional.

Begitu pula dalam Perempuan Berkalung Sorban, Anisa adalah seorang anak yang dibesarkan di lingkungan pesantren. Dia sering menentang ajaran pesantren yang melecehkan perempuan. Namun usahanya selalu gagal. Saat dia mengalami frustasi dan putus asa, hanya ada seorang laki-laki, Khadari, yang menjadi tempat curhat dan minta pertolongan. Khadari adalah satu-satunya orang yang memahami kondisinya. Bahkan saat Khadari meninggal, Anisa menampakkan kesedihan mendalam seolah kehidupannya telah hancur. Meski di akhir cerita dia tampil sebagai perempuan tegar, dia pernah mengalami ketergantungan emosional pada Khadari sampai kematian memisahkan mereka.

Berbeda dari film-film di atas, Laskar Pelangi tak merekam kisah percintaan. Bu Muslimah adalah seorang guru yang mengabdikan dirinya untuk memertahankan satu-satunya sekolah Islam miskin di Belitung. Saat Bakri menyatakan ingin pindah mengajar, dia merasa 
kesal karena Bakri meremehkan dan tak memedulikan sekolah itu lagi. Namun kepeduliannya terhadap sekolah ternyata dikalahkan oleh kesedihannya atas kematian Pak Harfan. Lima hari dia berkabung dan tak pernah datang ke sekolah. Bahkan hampir tak ada hasrat untuk mengajar lagi. Hingga akhirnya dia menyadari kesalahannya dengan bantuan Pak Zul. Dengan kata lain, kepeduliannya terhadap sekolah ternyata tergantung pada keberadaan Pak Harfan.

Sementara dalam Ketika Cinta Bertasbih, perempuan yang direpresentasikan memilki ketergantungan emosional adalah Tiara. Dia memohon sambil menangis agar Fadhil cepat-cepat melamarnya, seolah dia tak dapat bahagia tanpa Fadhil. Meski pemeran utama, Ana, tak menampakkan ketergantungan emosional, dia sangat mengagumi Azzam. Saat mengetahui akan menikah dengan Azzam, dia bersujud syukur.

Dari berbagai alur cerita yang ditampilkan dalam film bernuansa Islami, terlihat pemeran utama perempuan selalu mengalami masa tragis yang biasanya ditampakkan dengan kesedihan mendalam. Perempuan tenggelam dalam kesedihan saat hubungan dengan lakilaki pujaannya hancur. Ini berbeda dari laki-laki yang tak pernah direpresentasikan memiliki ketergantungan emosional.

\section{Hilangnya Kepahlawanan Perempuan}

Hegemoni makna yang terungkap dalam representasi perempuan diperkuat dengan adanya semacam kisah kepahlawan dalam alur cerita film. Meski tak sehebat pahlawan dalam film klasik, pahlawan dalam film modern juga muncul saat seorang laki-laki datang menyelamatkan perempuan dari jurang kehancuran. Ayat-ayat Cinta merupakan film yang memuat banyak kisah kepahlawanan. Fahri membantu Nauroh keluar dari penderitaan, terbebas dari siksaan ayah tirinya, dan memertemukannya dengan ayah aslinya. Fahri juga menyelamatkan Maria dari penyakit yang dideritanya. Hanya melalui sentuhan Fahri, Maria berangsur sembuh dan menemukan kebahagiaannya. Selain itu, saat Aisyah pergi dari rumah karena terbakar api cemburu, lagilagi Fahri datang menjemput dan menasehatinya, hingga Aisyah menyadari kesalahannya.

Begitu pula dalam Perempuan Berkalung Sorban, Anisa menjalani 
kehidupan yang pedih, terutama bersama suami pertamanya. Hanya Khadari satu-satunya orang yang mampu menenangkannya. Dia mengajak Khadari kabur, tapi Khadari menyatakan bahwa itu bukan jalan keluar yang baik. Meski sebenarnya ibu Anisa yang tampil sebagai pembela yang gigih, tapi hal itu terjadi karena penyiksaan terhadap Anisa sudah melampaui batas: Anisa dilempari batu oleh penghuni pesantren. Sementara kepahlawanan Khadari muncul saat Anisa di Jogja dan menikah. Khadari membantu Anisa mendapatkan pekerjaan. Khadari juga menyelamatkan Anisa dari trauma diperlakukan kasar oleh suami pertamanya. Selain itu, Khadari juga selalu menasehati Anisa supaya tidak bersikap keras kepala di lingkungan pesantren. Meski akhirnya, Anisa menjadi sosok teladan yang memerjuangkan kebebasan perempuan dan disegani di kalangan pesantren.

Berbeda dari film-film di atas yang mengaitkan kepahlawanan dengan kisah cinta, Laskar Pelangi memiliki kisah kepahlawanan yang berbeda. Saat Bu Muslimah berkabung dalam kesedihan setelah Pak Harfan meninggal, Pak Zul datang menasehatinya. Hingga akhirnya dia menyadari kesalahannya dan dapat keluar dari masa berkabungnya. Kalau saja Pak Zul tak datang saat itu, mungkin $\mathrm{Bu}$ Muslimah akan terus berkabung dan tak lagi mengajar. Lagilagi, seorang pahlawan adalah laki-laki yang datang menyelamatkan perempuan dari penderitaannya, bahkan saat perempuan itu sendiri tak mampu berbuat apa-apa.

Sementara Ketika Cinta Bertasbih, Azzam merupakan pahlawan kebanggaan keluarganya, karena dialah yang membiayai kehidupan mereka setelah ayahnya meninggal. Azzam juga pernah menjadi pahlawan saat Ana dan temannya bersedih di pinggir jalan karena kecopetan. Peristiwa itu yang membuat Ana mengaguminya.

Dengan demikian, hegemoni makna sebagai laki-laki dan perempuan terbentuk hampir tanpa cela: perempuan yang mudah tenggelam dalam kesedihan dan laki-laki yang datang menyelamatkannya dari penderitaan. Tak heran kalau penonton, yang tentunya mudah terhanyut dalam naturalisasi makna tersebut, akan memandang bahwa identitas sebagai laki-laki lebih unggul daripada sebagai perempuan, apalagi setelah diperkuat oleh fenomena sosial yang mewujud di sekitarnya. Misalnya dalam kehidupan sehari-hari 
sering ditemukan ungkapan bahwa laki-laki tak boleh cengeng, yang menunjukkan bahwa perempuan dianggap lumrah menjadi cengeng. Konstruksi identitas itulah yang direpresentasikan dan sosialisasikan oleh film bernuansa Islami. Hegemoni kultural tersebut hadir membayang-bayangi baik penonton laki-laki maupun perempuan.

\section{Hilangnya Kepemimpinan Perempuan}

Kehidupan sosial tak lepas dari beragam persoalan yang harus dicari solusinya. Begitu pula beragam film yang menampilkan kisah para aktor dengan pelbagai persoalan hidup. Kekuatan cerita dalam film terletak pada ketegangan-ketegangan yang terjadi sepanjang alur cerita. Karena itulah diperlukan cara tertentu untuk menyikapi dan mengatasinya. Siapa yang berperan besar dalam mengatasi persoalan tersebut? Atau siapa yang memimpin dan mengambil keputusan dalam mengatasi persoalan tersebut? Di sinilah konstruksi peran diwacanakan dalam film bernuansa Islami.

Dalam film Ayat-ayat Cinta, di awal cerita Maria berinisiatif membantu menyelesaikan tesis Fahri, namun sifat kepemimpinan itu tak sebesar persoalan yang diderita sepanjang hidupnya, yaitu tenggelam dalam kesedihan mendalam sampai Fahri datang sebagai penolong. Begitu pula saat Nauroh disiksa oleh ayah tirinya, Fahri berinisiatif membantu mencarikan orang tua aslinya, sementara Maria dan Nurul nampak ragu-ragu untuk terlibat menolongnya. Sementara Aisyah pernah menyatakan, setelah saling berargumen, bahwa Fahri adalah imam keluarga yang paling berhak mengambil keputusan. Meski Aisyah pernah berperan aktif untuk membebaskan Fahri dari penjara, namun itu pun karena terpaksa dan Fahri yang mengarahkannya menemukan bukti-bukti dari dalam penjara. Bahkan saat Aisyah tak dapat menahan kecemburuan dan pergi meninggalkan rumah, Fahri pula yang menjemputnya dan mengatasi persoalan tersebut. Selain itu, banyak peran penting di ruang publik yang tak melibatkan perempuan, seperti ulama, intelejen, hakim, pengacara dan sebagainya. Hanya ibu Maria yang bekerja di ranah publik sebagai dokter, itu pun tak bersinggungan dengan persoalan sosial dan kepemimpinan.

Dalam film Perempuan Berkalung Sorban, ayah Anisa sebagai 
pimpinan pesantren berperan aktif menasehati dan mengajarkan doktrin-doktrin pesantren. Sementara ibu Anisa hanya berperan membelanya saat dikasari dan dilempari batu. Dia tak berani menentang, atau lebih tepatnya hanya menuruti, pemahaman suaminya. Namun setelah suaminya meninggal, dia disegani dan berani bertindak tegas terhadap penghuni pesantren yang bersikap kasar. Meski demikian, pegelolaan pesantren tetap dilanjutkan oleh anak laki-lakinya. Sementara Anisa pernah berperan aktif dalam organisasi yang membela hak-hak perempuan, namun dalam dinamika keluarganya dia mengalami trauma sampai Khadari berhasil membantunya keluar dari trauma itu. Bahkan Khadari berhasil menenangkan dan menganjurkannya untuk tidak bersikap keras kepala kepada penghuni pesantren. Meski akhirnya Anisa berhasil diterima dan disegani di kalangan pesantren. Namun dalam keseluruhan cerita, perempuan masih ditempatkan di bawah kepemimpinan suaminya.

Begitu pula dalam film 3 Doa 3 Cinta, kiai berperan besar di pesantren. Tak ada perempuan yang terlibat persoalan sosial. Hanya Dona yang pernah membantu Huda mencari alamat ibunya di Jakarta, itu pun setelah didesak Huda. Bahkan peran perempuan di ranah publik bersifat negatif sebagai penyanyi pasar malam.

Dalam film Laskar Pelangi yang merekam dunia pendidikan, meski Bu Muslimah berperan aktif dalam membimbing muridmuridnya, namun permasalahan sekolah selalu ditangani oleh Pak Harfan. Bahkan setelah Pak Harfan meninggal dan Bu Muslimah berkabung, Pak Zul yang datang menyelamatkan keberlangsungan pendidikan sekolah. Selain itu, terdapat juri perempuan dalam acara cerdas cermat antarsekolah yang sikapnya cenderung negatif, yaitu mencurigai Sekolah Muhammadiyah berbuat curang.

Sementara dalam film Ketika Cinta Bertasbih, perempuan berperan aktif dalam ranah publik, seperti Eliana yang sibuk dengan pelbagai acara atau Ana yang pernah tampil sebagai moderator dan pembicara. Bahkan Ana pernah ditampilkan berani mengemukakan syarat saat dilamar Furqan, yang mampu membuat orang-orang di sekitarnya terkesan. Namun saat menghadapi sebuah persoalan, perempuan cenderung bersikap pasif, misalnya saat Ana dan temannya 
mengalami kecopetan. Ini berbeda dari Azzam yang bersikap tegas dalam beragam situasi; begitu pula ayah Ana sebagai tokoh masyarakat yang banyak berperan dalam mengarahkan kehidupan keluarganya. Karena itulah peran aktif perempun masih bisa dianggap lemah saat bersinggungan dengan peran yang dimainkan laki-laki.

Dengan demikian, konstruksi peran perempuan memiliki keterkaitan erat dengan konstruksi identitas. Perempuan ditempatkan pada posisi yang lemah dalam sistem sosial dan ditampilkan kurang mampu mengatasi pelbagai persoalan sosial. Karenanya, keterkaitan antara konstruksi identitas dan peran perempuan mengarah pada praktik hegemoni sosial atau kultural.

\section{Perempuan dalam Lintas Wacana}

Dari kemampuannya menarik perhatian masyarakat, film merupakan media yang paling mampu menyebarkan sebuah wacana. Tak heran kalau pemeran utama dalam film lebih populer daripada tokoh agama yang jarang muncul di berbagai media, terutama televisi. Karena itulah wacana yang disebarkan oleh berbagai film dapat dinyatakan sebagai wacana mayoritas yang paling populer di kalangan masyarakat, termasuk wacana perempuan. Apakah wacana perempuan Muslim dalam film memiliki keterkaitan dengan wacanawacana keislaman lainnya? Untuk menjawab persoalan ini, perlu dilakukan perbandingan antara wacana perempuan dalam film dan beragam wacana keislaman yang muncul dalam sejarah.

Wacana perempuan yang muncul pertama kali dalam sejarah Islam adalah para istri dan sahabat perempuan Rasulullah. Dalam sejarah Islam, Khadījah dikenal sebagai perempuan yang melindungi Rasulullah dari berbagai rongrongan kaum Quraysy. Berbeda dari perempuan dalam film bernuansa Islami, selalu suami yang berperan melindungi istrinya. Bahkan Sakinah bint Husayn, cucu perempuan Rasulullah, pernah menceraikan suaminya saat memergokinya bersama salah seorang pelayan perempuannya. ${ }^{40} \mathrm{Hal}$ itu menunjukkan tak ada ketergantungan istri terhadap suaminya. Karenanya, pemeran perempuan yang direpresentasikan dalam wacana film bertentangan dengan wacana perempuan Muslim awal yang masih tersimpan rapi dalam ruang perpustakaan dan seolah lenyap dalam wacana populer. 
Kepatuhan dan ketergantungan perempuan terhadap suami muncul dalam wacana perempuan sebagai jawari. Para jawari adalah perempuan yang hanya berperan sebagai penghibur. Tak ada yang dapat mereka lakukan kecuali mematuhi suami atau majikan mereka. Namun kita melihat perbedaan representasi di sini: kalau para jawari dipaksa untuk patuh, perempuan dalam film dengan suka rela menggantungkan nasibnya pada laki-laki pujaannya.

\section{Simpulan}

Naturalisasi makna yang direpresentasikan dalam film bernuansa Islami hanya merupakan konstruksi sosial: sebuah wacana dalam memandang realitas sosial. Karenanya, selalu ada celah untuk memandangnya sebagai sesuatu yang tidak natural, atau bahkan menyusun ulang jejaring pemaknaan yang telah ditetapkan dalam wacana tersebut.

Dari analisis wacana terhadap lima film bernuansa Islami, dapat ditarik beberapa kesimpulan:

Konstruksi identitas perempuan: pemeran utama perempuan dalam film bernuansa Islami selalu ditampilkan sebagai sosok yang memiliki ketergantungan emosional terhadap laki-laki pujaannya. Ketergantungan itu pun dipertegas dengan adanya kisah kepahlawanan laki-laki yang hadir sebagai penolong saat perempuan terjerembab dalam kesusahan dan kesedihan.

Konstruksi peran perempuan: sosok perempuan sebagai ibu atau istri sering direpresentasikan sedang memasak dan menyiapkan makanan bagi anggota keluarga, hanya Khadari (PBS) yang pernah membantu istrinya memasak. Bahkan dalam berinteraksi sosial, peran perempuan ditampilkan lebih lemah daripada laki-laki: selalu lakilaki yang mengambil keputusan dan mengatasi pelbagai persoalan.

Hegemoni Kultural: naturalisasi makna perempuan membentuk wacana tertentu sebagai acuan penonton dalam memandang dan menyikapi realitas sosial. Keseragaman konstruksi tersebut menyingkirkan beragam wacana alternatif yang muncul dalam lintas sejarah, misalnya wacana tentang kerabat dan sahabat Rasul atau ratu Muslim Nusantara. Wacana perempuan mengarah pada jejaring pemaknaan yang bertentangan dengan wacana keislaman lainnya. 


\section{Catatan Akhir}

1 Anthoni Giddens, Runaway World, terj. A. Puspo Kuncoro (Jakarta: Gramedia, 2001), 8.

2 Chris Barker, Cultural Studies: Teori dan Praktik, terj. Tim KUNCI Cultural Studies Center (Yogyakarta: Bentang, 2005), 86.

3 George Ritzer dan Douglas J. Goodman, Teori Sosiologi Modern, terj. Alimandan (Jakarta: Kencana, 2004), 287.

${ }^{4}$ Augie Fleras dan Jean Lock Kunz, Media and Minorities (Canada: Thomson Educational Publishing, tt.), 121.

5 Marianne W. Jorgensen dan Louise J. Pilips, Analisis Wacana: Teori dan Metode, terj. Abdul Syukur Ibrahim (Yogyakarta: Pustaka Pelajar, 2007), 89.

${ }^{6}$ Chris Barker, Cultural Studies: Teori dan Praktik, 10.

7 Barker, Cultural Studies, 233.

8 Barker, Cultural Studies, 14.

9 Jorgensen dan Philip, Analisis Wacana, 78.

${ }^{10}$ Doyle Paul Johnson, Teori Sosiologi Klasik dan Modern, terj. Robert M. Z Lawang, Jilid II (Jakarta: Gramedia, 1986), 23.

${ }^{11}$ Doyle Paul Johnson, Teori Sosiologi Klasik dan Modern, 37.

${ }^{12}$ Doyle Paul Johnson, Teori Sosiologi Klasik dan Modern, 43.

${ }^{13}$ John Storey, Pengantar Komprehensif Teori dan Metode Cultural Studies dan Kajian Budaya Pop, terj. Laily Rahmawati (Yogyakarta: Jalasutra, 2007), 20.

${ }^{14}$ Barker, Cultural Studies, 345.

${ }^{15}$ Storey, Cultural Studies, 17.

${ }^{16}$ Barker, Cultural Studies, 341.

${ }^{17}$ Marianne W. Jorgensen, Louise J. Pilips, Abdul Syukur Ibrahim (ed.), Analisis Wacana: Teori dan Metode (Yogyakarta: Pustaka Pelajar, 2007), 11.

${ }^{18}$ Eriyanto, Analisis Wacana: Pengantar Analisis Teks Media (Yogyakarta: LKiS, 2008), 34.

${ }^{19}$ John Fiske, Cultural Studies and Communication Studies: Sebuah Pengantar Paling Komprehensif, terj. Yosal Iriantara dan Idi Subandy Ibrahim (Yogyakarta: Jalasutra, 2007), 208.

${ }^{20}$ Marianne, Analisis Wacana, 9.

${ }^{21}$ Marianne, Analisis Wacana, 339.

${ }_{22}^{2}$ Marianne, Analisis Wacana, 8.

${ }^{23}$ Chris Barker, Cultural Studies, 10.

${ }^{24}$ Marianne, Analisis Wacana, 49.

${ }^{25}$ Marianne, Analisis Wacana, 50.

${ }^{26}$ Marianne, Analisis Wacana, 49.

${ }^{27}$ Marianne, Analisis Wacana, 52.

${ }^{28}$ Marianne, Analisis Wacana, 53.

${ }^{29}$ David Howarth, Discourse (Washington: Open University Press, 2000), 109.

${ }^{30}$ Annemari Schimmel, Jiwaku adalah Wanita (Bandung: Mizan, 1998), 59.

${ }^{31}$ Fatimah Mernissi, Pemberontakan Wanita, terj. Rahmani Astuti (Bandung: Mi- 
zan, 1999), 166.

${ }^{32}$ Mernissi, Pemberontakan Wanita, 177.

${ }^{33}$ Mernissi, Pemberontakan Wanita, 198.

${ }^{34}$ Mernissi, Pemberontakan Wanita, 153.

${ }^{35}$ M. Atho Mudzhar (ed.), Wanita dalam Masyarakat Indonesia: Akses, Pemberdayaan dan Kesempatan (Yogyakarta: Sunan Kalijaga Press), 286.

${ }^{36}$ Mudzhar, Wanita dalam Masyarakat Indonesia, 287.

${ }^{37}$ Mudzhar, Wanita dalam Masyarakat Indonesia, 288.

${ }^{38}$ Mudzhar, Wanita dalam Masyarakat Indonesia, 289.

39 "Fenomena Film Ayat-Ayat Cinta," Indo Forum, artikel diakses pada 12 Juli 2009 dari http://www. indoforum.org/showthread.php?p=693511

${ }^{40}$ Mernissi, Pemberontakan Wanita, 177.

\section{Daftar Pustaka}

Barker, Chris. Cultural Studies: Teori dan Praktik, terj. Tim KUNCI Cultural Studies Center. Yogyakarta: Bentang, 2005.

Eriyanto, Analisis Wacana: Pengantar Analisis Teks Media. Yogyakarta: LKiS, 2008.

Fenomena Film Ayat-Ayat Cinta, Indo Forum, artikel diakses pada 12 Juli 2009 dari http://www. indoforum.org/showthread. php?p=693511

Fiske, John. Cultural Studies and Communication Studies: Sebuah Pengantar Paling Komprehensif, terj. Yosal Iriantara dan Idi Subandy Ibrahim. Yogyakarta: Jalasutra, 2007.

Fleras, Augie dan Kunz, Jean Lock. Media and Minorities. Canada: Thomson Educational Publishing, tt.

Giddens, Anthoni. Runaway World, terj. A. Puspo Kuncoro. Jakarta: Gramedia, 2001.

Howarth, David. Discourse. Washington: Open University Press, 2000.

Johnson, Doyle Paul. Teori Sosiologi Klasik dan Modern, terj. Robert M. Z Lawang, Jilid II. Jakarta: Gramedia, 1986.

Jorgensen, Marianne W. dan Pilips, Louise J. Analisis Wacana: Teori dan Metode, terj. Abdul Syukur Ibrahim. Yogyakarta: Pustaka Pelajar, 2007.

Jorgensen, Marianne W. dkk. Analisis Wacana: Teori dan Metode. Yogyakarta: Pustaka Pelajar, 2007.

Mernissi, Fatimah. Pemberontakan Wanita, terj. Rahmani Astuti. 
Bandung: Mizan, 1999.

Mudzhar, M. Atho. Wanita dalam Masyarakat Indonesia: Akses, Pemberdayaan dan Kesempatan. Yogyakarta : Sunan Kalijaga Press.

Ritzer, George dan Goodman, Douglas J. Teori Sosiologi Modern, terj. Aliman. Jakarta: Kencana, 2004.

Schimmel, Annemari. Jiwaku adalah Wanita. Bandung: Mizan, 1998.

Storey, John Pengantar Komprehensif Teori dan Metode Cultural Studies dan Kajian Budaya Pop, terj. Laily Rahmawati. Yogyakarta: Jalasutra, 2007. 